\title{
PENINGKATAN BERAT BADAN IBU SAAT HAMIL BERHUBUNGAN DENGAN BERAT BADAN LAHIR BAYI
}

\author{
Subaim ${ }^{1}$,Lidya Ariyanti ${ }^{*}$ \\ 1PSIK Universitas Malahayati \\ 2Program Studi IImu Keperawatan Universitas Malahayati \\ *Korespondensi Email : lidya.arianti@yahoo.co.id
}

\section{ABSTRACT INCREASE IN MOTHER'S BODY WEIGHT DURING PREGNANCY RELATED TO BABY BIRTH WEIGHT}

Background: Infant mortality occurs in perinatal insanction (0 - 6 days), followed by death in neonatal indancy (7 - 28 days) and infant time ( $>28$ days-<1year). The cause of death of perinatal babies in Lampung Province in 2013 was caused by asphyxia by $37.14 \%$ and the largest neonatal death was caused by BBLR by $28.18 \%$.

Purpose : Known correlation of weight gain of mothers while pregnant with the results of baby birth weight in Ambon Market Bandar Lampung Year 2019

Methods: Quantitative research type, analytical survey research design with cross sectional approach. The population of 108 pregnant women based on the slovin formula was obtained by a sample of 85 respondents, sampling techniques using simple random sampling.Analyze univariate data and bivariate statistical tests using chi squaretest.

Result : From 85 respondents obtained 51 respondents (60.0\%) experienced normal weight gain, 34 respondents (40.0\%) abnormal weight gain, 58 respondents (68.2\%) with normal infant birth weight category, 27 respondents (31.8\%) with the weight category of babies born abnormally.

Conclusion : Statistical test results using chi square test are obtained $p$-value $=0.001<0.05)$ which means there is a correlation of increase in maternal weight while pregnant with the results of baby birth weight in Ambon Market Bandar Lampung City Year 2019.

Suggestion Pregnant women can maintain nutritional status from the beginning of the trimester to the end of the trimester through regular consumption of nutrients and energy according to the needs of the condition of the pregnant woman.

Keywords : BB Enhancement, Pregnant Women, Baby Birth Weight

\section{ABSTRAK}

Pendahuluan: Kematian bayi terjadi pada masa bayi perinatal ( 0 - 6 hari), diikuti kematian pada masa bayi neonatal ( $7-28$ hari) dan masa bayi (>28 hari-<1tahun). Penyebab kematian bayi perinatal Provinsi Lampung tahun 2013 disebabkan karena asfiksia sebesar 37,14\% dan kematian neonatal terbesar disebabkan BBLR sebesar28,18\%.

Tujuan:Diketahui korelasi peningkatan berat badan ibu saat hamil dengan hasil berat badan lahir bayi di Pasar Ambon Kota Bandar Lampung Tahun 2019.

Metode: Jenis penelitian kuantitatif, rancangan penelitian Survei Analitik dengan pendekatan crosssectional. Populasi 108 ibu hamil berdasarkan rumus slovin didapat sampel sebanyak 85 responden, teknik sampling menggunakan simple random sampling. Analisa data univariat dan bivariat, uji statistik menggunakan uji chisquare.

Hasil: Dari 85 responden didapat 51 responden $(60,0 \%)$ mengalami peningkatan berat badan normal, 34 responden $(40,0 \%)$ mengalami peningkatan berat badan tidak normal, 58 responden $(68,2 \%)$ dengan kategori berat lahir bayi normal, 27 responden $(31,8 \%)$ dengan kategori berat bayi lahir tidak normal.

Kesimpulan: Hasil uji statistik menggunakan uji chi square didapat nilai $p$-value $=0,001(<0.05)$ yang artinya terdapat korelasi peningkatan berat badan ibu saat hamil dengan hasil berat badan lahir bayi di Pasar Ambon Kota Bandar Lampung Tahun 2019.

Saran ibu hamil dapat menjaga status gizi mulai dari awal trimester hingga akhir trimester melalui konsumsi zat gizi dan energi yang teratur sesuai dengan kebutuhan kondisi ibuhamil.

Kata Kunci :Peningkatan BB, Ibu Hamil, Berat Badan Lahir Bayi 


\section{JKM (Jurnal Kebidanan Malahayati),Vol 7,No.4.Oktober 2021, ISSN (Print) 2476-8944 ISSN (Online) 2579-762X, Hal 818-823}

\section{PENDAHULUAN}

Masalah gizi masih merupakan masalah kesehatan masyarakat yang utama di negara berkembang termasuk Indonesia. Masalah gizi menjadi penyebab kematian ibu dan anak secara tidak langsung yang sebenarnya masih dapat dicegah. Rendahnya asupan gizi dan status gizi ibu hamil selama kehamilan dapat mengakibatkan berbagai dampak tidak baik bagi ibu dan bayi. Salah satunya adalah bayi lahir dengan berat badan lahir rendah (BBLR), yaitu berat badan lahir di bawah2500gram. BayiyangterlahirBBLR memiliki peluang meninggal 35 kali lebih tinggi dibandingkan dengan berat badan lahir di atas 2500 gram. Penurunan kejadian BBLR dapat dicapai melalui pengawasan pada ibu hamil dengan menemukan dan memperbaiki faktor yang mempengaruhi pertumbuhan dan perkembanganjanindanneonatus (Antono, 2011; Khoiriyah,2016)

Asupan energi dan protein yang tidak mencukupi pada ibu hamil dapat menyebabkan Kurang Energi Kronis (KEK). Berdasarkan PSG tahun 2016, 53,9\% ibu hamil mengalami defisit energi $(<70 \%$ AKE) dan 13,1\% mengalami defisit ringan (70-90\% AKE). Untuk kecukupan protein, $51,9 \%$ ibu hamil mengalami defisit protein $(<80 \%$ AKP) dan 18,8\% mengalami defisit ringan (80-99\% AKP). Salah satu identifikasi ibu hamil KEK adalah memiliki ukuran Lingkar Lengan Atas (LILA) $<23,5 \mathrm{~cm}$ (Kemenkes RI, 2019).

Masa kehamilan memerlukan perhatian khusus karena merupakan periode penting pada 1.000 hari kehidupan. Ibu hamil termasuk salah satu kelompok yang rawan gizi. Asupan gizi ibu hamil sangat berpengaruh terhadap pertumbuhan janin. Status gizi yang baik pada ibu hamil dapat mencegah terjadinya Berat Bayi Lahir Rendah (BBLR) dan stunting (pendek) (Kemenkes RI,2019).

Ibu hamil merupakan salah satu kelompok yang rawan akan masalah gizi. Hal tersebut bisa berakibat fatal bukan hanya untuk ibu tapi juga membahayakan anak di dalam kandungannya. Kondisi gizi seseorang dipengaruhi oleh status gizinya semasa dalam kandungan. Dengan kata lain status gizi ibu hamil merupakan hal yang sangat berpengaruh besar terhadap kesehatannya sendiri dan sebagai prediksi pregnancy outcome untuk ibu dan status gizi bayi barulahir (Senbanjo et al, 2013).

Hal ini disebabkan asupan makanan janin hanya dapat melalui tali pusat yang terhubung kepada tubuhibu (Indreswari et al, 2008). Status gizi ibu hamil tercermin dari ukuran antropometrinya. Ukuran antropometri ibu hamil sangat mempengaruhi berat bayi yang akan dilahirkan. Bila status gizi ibu sebelum hamil dalam kondisi baik maka ibu disemester I sebanyak 10.294 kasus. Demikian pula dengan angka kematian Ibu turun dari 4.999 tahun 2015 menjadi 4912 di tahun 2016 dan di tahun 2017 (semester I) sebanyak 1712 kasus (Kementerian Kesehatan,2019).

Upaya kesehatan anak telah menunjukkan hasil yang baik terlihat dari angka kematian anak dari tahun ke tahun yang menunjukkan penurunan. Hasil Survei Demografi dan Kesehatan Indonesia (SDKI) tahun 2017 menunjukkan AKN sebesar 15 per 1.000 kelahiran hidup, AKB 24 per 1.000 kelahiran hidup, dan AKABA 32 per 1.000 kelahiran hidup. Angka Kematian Balita telah mencapai ini digunakan untuk memonitor dan mengevaluasi program serta kebijakan kependudukan dan kesehatan. Program kesehatan Indonesia telah difokuskan untuk menurunkan tingkat kematian anak yang cukup tinggi. Berdasarkan SDGs jumlah kasus kematian Bayi turun dari mencerminkan tingkat pembangunan kesehatan dari suatu negara serta kualitas hidup dari masyarakatnya. Angka 33.278 di tahun 2015 menjadi 32.007 Angka kematian bayi dan anak pada tahun 2016, dan di tahun 2017 bulan dan berat badannya normal (Firdaus et al, 2014).

Target Pembangunan Berkelanjutan (TPB/SDGs) 2030 yaitu sebesar 25/1.000 kelahiran hidup dan diharapkan AKN juga dapat mencapai target yaitu 12/1.000 kelahiranhidup (Kemenkes $\mathrm{RI}, 2019)$.

Kematian bayi terjadi pada masa bayi perinatal $(0-6$ hari), diikuti kematian pada masa bayi neonatal $(7-28$ hari) dan masa bayi $(>28$ hari-<1tahun). Penyebab kematian bayi perinatal. Provinsi Lampung tahun 2013 disebabkan karena asfiksia sebesar $37,14 \%$ dan kematian neonatal terbesar disebabkan BBLR sebesar 28,18\% Penyebab kematian bayi masa perinatal terbanyak adalah asfiksia. Kejadian BBLR sangat dipengaruhi dari faktor ibu, faktor bayi dan faktor tali pusat (sepsis). ( Profil Kesehatan Provinsi Lampung, 2016).

Cakupan BBLR Berdasarkan Data Dinas Kota Bandar Lampung, dengan membandingkan 10 Puskesmas tertinggi, berada di Puskesmas Pasar Ambon dengan persentase $84,04 \%$, Puskesmas Bakung 40,59\%, Puskesmas Kupang Kota 34,81\%, Puskesmas Segala Mider 31,28\%, Puskesmas Sukaraja 25,85\%, Puskesmas Pinang Jaya 25,95\%, Puskesmas Sukamaju 24,83\%, Puskesmas Susunan Baru 22,87\%, Puskesmas Beringin Raya 22,02\%, dan Puskemas Korpri 21,26\% (Dinkes, Kota Bandar Lampung, 2019). 


\section{METODE PENELITIAN}

Jenis penelitian ini menggunakan kuantitatif, dengan rancangan penelitian deskriptif dengan pendekatan cross sectional, jumlah populasi dan sampel ibu hamil dan bayi baru lahir, teknik sampling menggunakan random sampling penelitian dilakukan pada bulan Agustus 2020 di Puskesmas Pasar Ambon Kota Bandar Lampung.

\section{HASIL DAN PEMBAHASAN}

Analisa Univariat

Tabel 1.

Distribusi Frekuensi Peningkatan Berat Badan Ibu Saat Hamil Di Pasar Ambon Kota Bandar Lampung

\begin{tabular}{lcc}
\hline Pertambahan BB & Frekuensi & $\%$ \\
\hline Normal Tidak & 51 & 60,0 \\
Normal & 34 & 40,0 \\
\hline \multicolumn{1}{c}{ Total } & $\mathbf{8 5}$ & $\mathbf{1 0 0}$ \\
\hline
\end{tabular}

Dari tabel 1 diatas dapat dilihat distribusi frekuensi peningkatan berat badan ibu saat hamil dari 85 responden didapat sebanyak 51 responden $(60,0 \%)$ mengalami peningkatan berat badan normal, sedangkan 34 responden $(40,0 \%)$ mengalami peningkatan berat badan tidak normal.

Tabel 2.

Distribusi Frekuensi Berat Badan Lahir Bayi Di Pasar Ambon Kota Bandar Lampung

\begin{tabular}{lcc}
\hline \multicolumn{1}{c}{ BB LahirBayi } & Frekuensi & $\%$ \\
\hline Normal & 58 & 68,2 \\
Tidak Normal & 27 & 31,8 \\
\hline \multicolumn{1}{c}{ Total } & 85 & 100 \\
\hline
\end{tabular}

Dari tabel 2 diatas dapat dilihat distribusi frekuensi berat badan lahir bayi dari 85 responden didapat sebanyak 58 responden $(68,2 \%)$ dengan kategori berat lahir bayi normal, dan 27 responden $(31,8 \%)$ dengan kategori berat bayi lahir tidak normal.

\section{Analisa Bivariat}

Tabel 3.

Korelasi Peningkatan Berat Badan Ibu Saat Hamil Dengan Hasil Berat Badan Lahir Bayi Di Pasar Ambon Kota Bandar Lampung

\begin{tabular}{|c|c|c|c|c|c|c|c|}
\hline \multirow{3}{*}{ Pertambahan BB } & \multicolumn{4}{|c|}{ Hasil Lahir } & \multirow{2}{*}{\multicolumn{2}{|c|}{ Total }} & \multirow{3}{*}{ P-Value } \\
\hline & \multicolumn{2}{|c|}{ Normal } & \multicolumn{2}{|c|}{ Tidak } & & & \\
\hline & $\mathrm{N}$ & $\%$ & $\mathbf{N}$ & $\%$ & $\mathbf{N}$ & $\%$ & \\
\hline Normal & 42 & 49,4 & 9 & 10,6 & 51 & 60,0 & 0001 \\
\hline Tidak Normal & 16 & 18,8 & 18 & 21,2 & 34 & 40,0 & 0,001 \\
\hline Total & 58 & 68,2 & 27 & 31,8 & 85 & 100 & \\
\hline
\end{tabular}

Dari table 3 Hasil uji statistik menggunakan uji chi square didapat nilai $p$-value $=0,001(<0.05)$ yang artinya terdapat korelasi peningkatan berat badan ibu saat hamil dengan hasil berat badan lahir bayi di Pasar Ambon Kota Bandar Lampung Tahun 2019, dengan $\mathrm{OR}=5,250$ yang artinya responden yang mengalami pertambahan berat badan tidak normal akan 5 kali beresiko memiliki berat badan lahir bayi tidak normal.

\section{PEMBAHASAN}

Analisa Univariat

Distribusi Frekuensi Peningkatan Berat Badan Ibu Saat Hamil Di Pasar Ambon Kota Bandar Lampung Tahun 2019

Hasil penelitian didapat dari 85 responden didapat sebanyak 51 responden $(60,0 \%$ mengalami peningkatan berat badan normal, sedangkan 34 responden $(40,0 \%)$ mengalami peningkatan berat badan tidak normal.
Sejalan dengan teori yang dikemukakanolehElshibly, E.M. \&Schmalisch, G (2008; Oktavina, 2016) Kehamilanmenyebabkan banyak perubahan pada tubuh ibu. Perubahan perubahan itu untuk menyesuaikan tubuh ibu pada keadaan kehamilannya,termasuk perubahan berat badan.

Sejalan dengan Maryunani (2013) menyatakan kehamilan yang perlu diwaspadai adalah jarak persalinan terakhir dengan awal kehamilan sekarang kurang dari 2 tahun, bila jarak terlalu dekat, maka rahim dan kesehatan ibu belum pulih dengan baik. Keadaan ini perlu di waspadai kemungkinan perubahan janin kurang baik, persalinan lama atau pendarahan. Seorang ibu memerlukan waktu 2 sampai 3 tahun antara kehamilan agar pulih secara fisiologis dan persalinan sebelumnya dalam mempersiapkan diri untuk kehamilan berikutnya. Semakin pendek jarak antara kehamilan sebelumnya semakin besar 


\section{JKM (Jurnal Kebidanan Malahayati),Vol 7,No.4.Oktober 2021, \\ ISSN (Print) 2476-8944 ISSN (Online) 2579-762X, Hal 818-823}

beresiko melahirkan bayi dengan berat badan tidak normal atau BBLR, hal tersebut disebabkan karena seringnya terjadi komplikasi pendarahan waktu hamil, partus premature dan anemia berat.

Sedangkan responden yang mengalami peningkatan berat badan tidak normal sebanyak 34 responden $(40,0 \%)$ memiliki berat badan lahir bayi dengan kategori normal sebanyak 16 responden $(18,8 \%)$ hal ini dapat disebabkan dari segi faktor status ekonomi sering dikaitkan dengan tingkat pendidikan seseorang, semakin tinggi status ekonomi seseorang akan semakin tinggi pula tingkat pendidikannya. Keluarga dengan tingkat pendidikan yang tinggi akan lebih mudah menerima informasi atau arahan tentang cara meningkatkan tumbuh kembang anak, penggunaan fasilitas kesehatan, serta pendidikan yang terbaik untuk anaknya dibandingkan keluarga dengan tingkat pendidikan rendah.

Distribusi Frekuensi Peningkatan Berat Badan Lahir Bayi Di Pasar Ambon Kota Bandar Lampung Tahun 2019

Hasil penelitian didapat dari 85 responden didapat sebanyak 58 responden $(68,2 \%)$ dengan kategori berat lahir bayi normal, dan 27 responden $(31,8 \%)$ dengan kategori berat bayi lahir tidaknormal.

Sejalan dengan teori yang dikemukakan oleh Kosim (2009) Berat bayi lahir adalah berat badan bayi yang di timbang dalam waktu 1 jam pertama setelah lahir. Hubungan antara berat lahir dengan umur kehamilan, berat bayi lahir dapat dikelompokkan bayi kurang bulan (BKB), yaitu bayi yang dilahirkan dengan masa gestasi $<37$ minggu (259 hari). Bayi cukup bulan (BCB), bayi yang dilahirkan dengan masa gestasi antara $37-42$ minggu (259 - 293 hari), dan bayi lebih bulan (BLB), bayi yang dilahirkan dengan masa gestasi > 42 minggu (294 hari).

Sejalan dengan penelitian yang dilakukan oleh Shidiq (2014) Hubungan Pertambahan Berat Badan Ibu Hamil terhadap Berat Bayi Lahir di Kota Pariaman. Metode penelitian adalah analitik yang dilakukan di kota Pariaman dengan menggunakan data ibu melahirkan mengetahui kekuatan dan arah hubungan antara variabel independen dengan berat lahir. Hasil penelitian menemukan rata-rata berat lahir 3.337,8 $\pm 353,7$ gram $(95 \% \mathrm{Cl}=3.292-3.383)$. Berat badan (BB) sebelum hamil, pertambahan berat badan ibu trimester pertama, kedua, dan ketiga mempunyai kekuatan hubungan yang sedang dan berpola positif. Model prediksi menunjukkan bahwa berat lahir $=1.764,133+0,023$ (BB prahamil) +0,131 (pertambahan berat badan trimester 1) $+0,037$ (pertambahan berat badan trimester 2) $+0,037$ (pertambahan berat badan trimester 3). Variabel yang paling berpengaruh adalah pertambahan berat badan trimester pertama. Sejalan dengan teori yang dikemukakan oleh Elshibly,E.M. \&Schmalisch, G (2008; Oktavina, 2016) Kehamilan menyebabkan banyak perubahan pada tubuh ibu. Perubahan - perubahan itu untuk menyesuaikan tubuh ibu pada keadaan kehamilannya,termasuk perubahan berat badan. Penggunaan zat- zat makanan oleh tubuh menurun pada 4 bulan pertama kehamilan sehingga kebutuhan tubuh akan makanan juga berkurang pada beberapa bulan pertama kehamilan.

Menurut Budiman (2011), semakin berat badan ibu hamil, semakin bertambah juga berat bayi lahir. Berat badan ibuhamil merupakan komponen hasil penjumlahan berat badan ibu sebelum hamil dan kenaikan berat badan selama kehamilan. Kenaikan berat badan selama kehamilan merupakan gambaran laju pertumbuhan janin dalam kandungan yang perlu diperhatikan karena kenaikan berat badan yang kurang maupun berlebih dapat menimbulkan permasalahan yang serius bagi ibu danbayinya.

Menurut peneliti pertambahan berat badan ibu selama hamil adalah ukuran yang paling umum untuk melihat status gizi wanita hamil dan janin selama kehamilan. Pertambahan berat badan ibu selama masa kehamilan terjadi karena adanya pertumbuhan janin, plasenta, dan perubahan metabolik tubuh dari ibu.

\section{Analisa Bivariat}

Korelasi Peningkatan Berat Badan Ibu Saat Hamil Dengan Hasil Berat Badan Lahir Bayi Di Pasar Ambon KotaBandar Lampung Tahun 2019

Hasil uji statistik menggunakan uji chi square didapat nilai $p$-value $=0,001(<0.05)$ yang artinya terdapat korelasi peningkatan berat badan ibu saat hamil dengan hasil berat badan lahir bayi di Pasar Ambon Kota Bandar Lampung Tahun 2019, dengan $\mathrm{OR}=5,250$ yang artinya responden yang mengalami pertambahan berat badan tidak normal akan 5 kali beresiko memiliki berat badan lahir bayi tidak normal. Berdasarkan penelitian Lathifah,2019 terdapat 17 orang ibu hamil yang memiliki kenaikan berat badan tidak sesuai IMT dan melahirkan bayi dengan Berat bayi lahir tidak sesuai dan terdapat 9 orang yang kenaikan berat badannya tidak sesuai IMT tetapi Berat Bayi Lahir sesuai, Terdapat 2 orang ibu hamil yang memiliki kenaikan berat badan tidak sesuai IMT dan melahirkan Bayi dengan Berat bayi lahir tidak sesuai dan terdapat 12 orang ibu 
hamil yang kenaikan berat badannya sesuai IMT dan berat bayi lahir sesuai IMT dan mempunya PValue $0,002<0,05$ yang artinya terdapat hubungan antara kenaikan berat badan ibu hamil terhadap berat badan bayi lahir. Dari hasil penelitan diatas terdapat ibu hamil yang kenaikan berat badannya tidak sesuai tetapi mempunyai berat bayi lahir sesuai, dan ibu hamil dengan kenaikan berat badan yang sesuai tetapi berat bayi lahirnya tidak sesuai, hal ini dapat disebabkan karena ada factor lain yaitu usia kehamilan dan paritas.

Sejalan dengan teori yang dikemukakan oleh Firdaus dkk (2014) peningkatan berat badan selama hamil sangat bervariasi mulai dari 9 sampai $12 \mathrm{~kg}$ dengan peningkatan berat badan paling cepat biasanya terjadi pada minggu 24 dan 32 . Rahim, janin, plasenta dan cairan yang ada di dalamnya akan menyebabkan berat badan meningkat lebih dari separuh total berat badan.

Penambahan berat badan yang lebih kecil adalah akibat perubahan metabolic yang menyebabkan bertambahnya air dalam sel dan penumpukan lemak dan protein baru. Lemak bawah kulit pada umumnya tertimbun di bagian perut serta bagian depan dan belakang paha terutama pada trimester pertama dan kedua. Bertambahnya berat badan ibu sangat berarti sekali bagi kesehatan ibu dan janin. Pada ibu yang menderita kekurangan energi dan protein (status gizi kurang) maka akan menyebabkan ukuran plasenta lebih kecil dan suplai nutrisi dari ibu ke janin berkurang, sehingga terjadi retardasi perkembangan janin intra uteri dan bayi dengan Berat Bayi Lahir Rendah (BBLR) (Puspitasari C,2011).

Sejalan dengan penelitian yang dilakukan oleh Sudiarti (2013) Model Prediksi Berat Lahir Bayi Berdasarkan Berat Badan Ibu Hamil. Analisis korelasi dan regresi linier ganda digunakan untuk mengetahui kekuatan dan arah hubungan antara variabel independen dengan berat lahir. Hasil penelitian menemukanrata-rata berat lahir 3.337,8 \pm 353,7 gram $(95 \% \mathrm{Cl}=3.292-3.383)$. Berat badan (BB) sebelum hamil, pertambahan berat badan ibu trimester pertama, kedua, dan ketiga mempunyai kekuatan hubungan yang sedang dan berpola positif. Model prediksi menunjukkan bahwa berat lahir $=1.764,133+0,023(\mathrm{BB}$ pra hamil $)+0,131$ (pertambahan berat badan trimester 1 ) $+0,037$ (pertambahan berat badan trimester 2) $+0,037$ (pertambahan berat badan trimester 3). Variabel yang paling berpengaruh adalah pertambahan berat badan trimester pertama.

Responden dengan peningkatan berat badan normal sebanyak 51 responden $(60,0 \%)$ memiliki berat badan lahir bayi dengan kategori tidak normal sebanyak 9 responden (10,6\%) Paritas atau jumlah anak yang pernah dilahirkan paling aman di tinjau dari sudut kematian maternal dan perinatal adalah paritas 2-3 atau. Paritas 1 dan $>4$ mempunyai angka kematian maternal lebih tinggi. Paritas yang terlalu tinggi akan mengakibatkan terganggunya uterus terutama dalam hal pembuluh. Kehamilan yang berulang-ulang akan menyebabkan kerusakan pada dinding pembuluh darah uterus. hal ini akan mempengaruhi nutrisi ke janin pada kehamilan selanjutnya, selain itu dapat menyebabkan atoniauteri.

Menurut pendapat peneliti kelebihan berat badan ataupun kekurangan berat badan pada ibu hamil dapat menghambat perkembangan janin. Makin tinggi bertambahnya berat badan ibu hamil ada kemungkinan janin akan mengalami makrosomia. Bila berat badan ibu yang rendah selama kehamilan akan menyebabkan tubuh kembang janin mengalami hambatan sehingga jadi intrauterine growth retardation, persalinan prematuretas dan berat badan lahir rendah untuk masa gestasinya.

Berbagai faktor yang mempengaruhi berat lahir bayi antara lain meliputi jenis kelamin bayi, ras, keadaan plasenta, umur ibu, aktivitas ibu, kebiasaan merokok, paritas, jarak kelahiran, tinggi badan dan berat badan ibu sebelum kehamilan,status sosial ekonomi, gizi, pemanfaatan pelayanan kesehatan dan pertambahan berat badan ibu selama kehamilan. Namun, hubungan antara status gizi ibu dan berat lahir dalam kelangsungan hidup anak, yang konsisten adalah 1) ukuran tubuh ibu, yaitu tinggi dan berat ibu sebelum hamil, dan 2) pertambahan berat, yaitu sejumlah pertambahan berat ibu selama kehamilannya.

\section{SIMPULAN}

Terdapat korelasi peningkatan berat badan ibu saat hamil dengan hasil berat badan lahir bayi di Pasar Ambon Kota Bandar Lampung Tahun 2019, dengan $\mathrm{OR}=5,250$ yang artinya responden yang mengalami pertambahan berat badan tidak normal akan 5 kali beresiko memiliki berat badan lahir bayi tidak normal.

\section{SARAN}

Diharapkan pemberi layanan kesehatan memberikan informasi, edukasi, dan motivasi pada ibu hamil untuk mengontrol kenaikan berat badan ibu. Diharapkan hasil penelitian ini nantinya dapat menambah literatur tentang korelasi peningkatan berat badan ibu.Diharapkan ibu dapat meningkatkan berat badan ibu hamil sesuai dengan usia kehamilan, sehingga saat bayi lahir sesuai 
dengan berat badan lahir bayinya.

\section{DAFTAR PUSTAKA}

Andriyani (2016). Hubungan Indeks Massa TubuhdenganKejadianPreeklampsia di RSUP Dr. M. Djamil Padang.

Arisman,MB.(2010).Gizi Dalam Kehidupan. Jakarta :EGC.

Hardinsyah, M. S., \&Supariasa, I. D. (2017). IImu gizi teori dan aplikasi. Jakarta:EGC.

Hermawan,B.V.(2019).Gambaran Indeks Massa Tubuh Mahasiswa Div Kebidanan Fakultas IImu Kesehatan Universitas Ngudi Waluyo Tahun Ajaran 2018/2019 (Doctoral Dissertation, Universitas Ngudi Waluyo).

Hidayati, A. (2017). Hubungan Usia Gestasi Dengan Kejadian Hiperbilirubinemia Pada Bayi Dengan Berat LahirRendah (Bblr) Di Rsud Wonosari(Doctoral

Dissertation, Universitas Gadjah Mada).

Jannah, Nurul. (2019). Buku Ajar Asuhan Kebidanan Kehamilan. Yogyakarta: Andi Ofset.

Lathifah, N. S. (2019). Hubungan Kenaikan Berat Badan Ibu Selama Hamil Terhadap Berat Badan Bayi Saat Lahir Di Bps Wirahayu Panjang Bandar Lampung. Jurnal Ilmu Kedokteran Dan Kesehatan, 6(4), 274-279.

Maulana. (2012). Panduan Lengkap Kehamilan. Kata hati: Yogyakarta.

Marie,CM.(2002).BukuPedomanDietdan Nutrisi Edisi II. Jakarta:Hipokrates.

Mochtar, R. (2013). Sinopsis Obstetri Fisiologi dan Patologi edisi 2.EGC: Jakarta.

Ningrum., Cahyaningrum. (2018). Status Gizi Pra Hamil Berpengaruh Terhadap Berat Dan
Panjang Badan Bayi Lahir. 1Prodi Kebidanan D3, STIKES Harapan Bangsa Purwokerto, Jawa Tengah.

Profil Kemenkes RI (2018). Angka Kematian Ibu Dan Bayi.

Profil Kemenkes RI. (2016). Angka Kejadian KEK.

Profil Kemenkes RI. (2017). Angka Kejadian KEK.

Profil Kemenkes RI. (2019). Angka Kejadian KEK.

Proverawati, A. Sulistyorini, 2010. BBLR (Berat Badan Lahir Rendah) Dilengkapi Dengan Asuhan Pada BBLR Dan Pijat Bayi.

Puspitasari. C, Anasari. T danFajarsari.D. (2011). Hubungan Antara Kenaikan Berat Badan Selama Kehamilan dengan Berat Bayi Baru Lahir di Wilayah Kerja Puskesmas Rawalo Kabupaten RawaloTahun 2009 - 2010. Bidan Prada. Jurnal IImiah Kebidanan. Vol. 2. No. 1. EdisiJuni.

Rukiyah, A. Y. (2015). Yulianti L. Asuhan kebidanan IV (patologi kebidanan). Jakarta Trans Info Media.

Sarwono, Prawirohardjo. (2014). Acuhan Nasional Pelayanan Kesehatan Maternal Dan Neonatal. PT Bina Pustaka Sarwono Prawirohardjo.

Sukarni, Icesmi K. (2019). Kehamilan Persalinan dan Nifas. Yogyakarta: Nuha Medika.

Supariasa. (2012). Penilaian Status Gizi.Jakarta: EGC.

Wardiyah, A., Rilyani. (2016). Sistem Reproduksi (Lengkap Dengan Latihan Uji Kompetensi Perawat). Jakarta: SalembaMedika.

Yongky, Dkk. (2009). Status Gizi Awal Kehamilan Dan Pertambahan Berat Badan Ibu Hamil Kaitannya Dengan BBLR. Sekolah Pascasarjana Institut Pertanian Bogor,Bogor 